\title{
Result of Vanilla (Vanilla Planifolia) Adaptation Study in Ethiopia
}

\author{
Habetewold Kifelew, Girma Hailemichael, Zenebe Mulatu, Dejene Bekelle, Abukiya \\ Getu, Haimanot Mitiku, Tesfaye Tefera
}

Tepi National Spices Research Center, P.O. Box: 34, SNNPRS, Sheka, Tepi

kifelew@yahoo.com

\begin{abstract}
Vanilla (Vanilla planifolia) is the only genus of the Orchidaceae family whose species produces a commercially important flavoring material. The study was conducted to evaluate the adaptability of introduced vanilla genotype in Ethiopia. A single observation plot was established in three locations. Vanilla was found adaptable in all location with comparable yield and quality. And results one variety with the name "Yeki 1" were registered for production.
\end{abstract}

Keyword: vanilla, adaptation.

\section{INTRODUCTION}

Vanilla (Vanilla planifolia) is the only genus of the Orchidaceae family whose species produces a commercially important flavoring material (Severine Bory et al., 2008). Out of 110 known species of Vanilla only Vanilla tahitensis, Vanilla pompoa and Vanilla planifolia Andrews are commercially cultivated today (Ranadive, 1994). In Ethiopia 178 species in 38 genera of Orchidaceae have been documented in field guide to Ethiopian orchids by Sebsebe Demissew et al (2004), from them two of which are vanilla origin V. Imperalis and V.roschei rchb.f. but, the cultivated vanilla Vanilla planifolia has been introduced in to Ethiopia from Indonesia Bali island in 1993 and subsequent work have been done to see its adaptability at different locations of Ethiopia

Vanilla is mainly responsible for the fragrance, flavor and aroma of vanilla essence and the secondmost expensive spice (after saffron). It is used in the preparation of ice cream, chocolates, cakes, pastries, puddings, soft drinks, pharmaceuticals, liquors, and perfumery and in nutraceuticals (Ranadive, 1994).

World production of cured vanilla beans averages between 2,000 and 3,000 Mts. per year, Madagascar is the largest producer, with 1,000 to 1,500 Mts, followed by Indonesia, with 700 to 800 Mts. and Comoro, with average production of 200 Mts. per year (). Although vanilla products are traded globally, the United States, France, and Germany are the primary importers of vanilla beans. They are major re-exporters of both processed vanilla extract and repackaged fresh beans to other countries (ADC, 2000).

His study was conducted based on the objective of evaluation of vanilla fragrance adaptability in south west Ethiopia for registering and promoting for production.

\section{MATERIALS AND METHODS}

\subsection{Description of the Study Area}

Table1. Summary of agro ecological description of the testing locations

\begin{tabular}{|l|l|l|l|}
\hline Description & Tepi & Bebeka & Shosha \\
\hline Average annual Temperature $\left({ }^{\mathrm{O}} \mathrm{C}\right)$ & $15.3-29.5$ & $15.1-27$ & $29.5-15.3$ \\
\hline Average annual Rainfall $(\mathrm{mm})$ & 1688 & $400-2000$ & 1688 \\
\hline Altitude (m.a.s.l) & 1200 & $500-1200$ & 1200 \\
\hline Longitude & $35^{\circ} 0^{\prime} \mathrm{E}$ & $34.88-36.14$ & $35^{\circ} 0^{\prime} \mathrm{E}$ \\
\hline Latitude & $7^{\mathbf{0}^{\prime}} 3^{\prime} \mathrm{N}$ & $7.21-5.33$ & $7^{\circ} 3^{\prime} \mathrm{N}$ \\
\hline
\end{tabular}




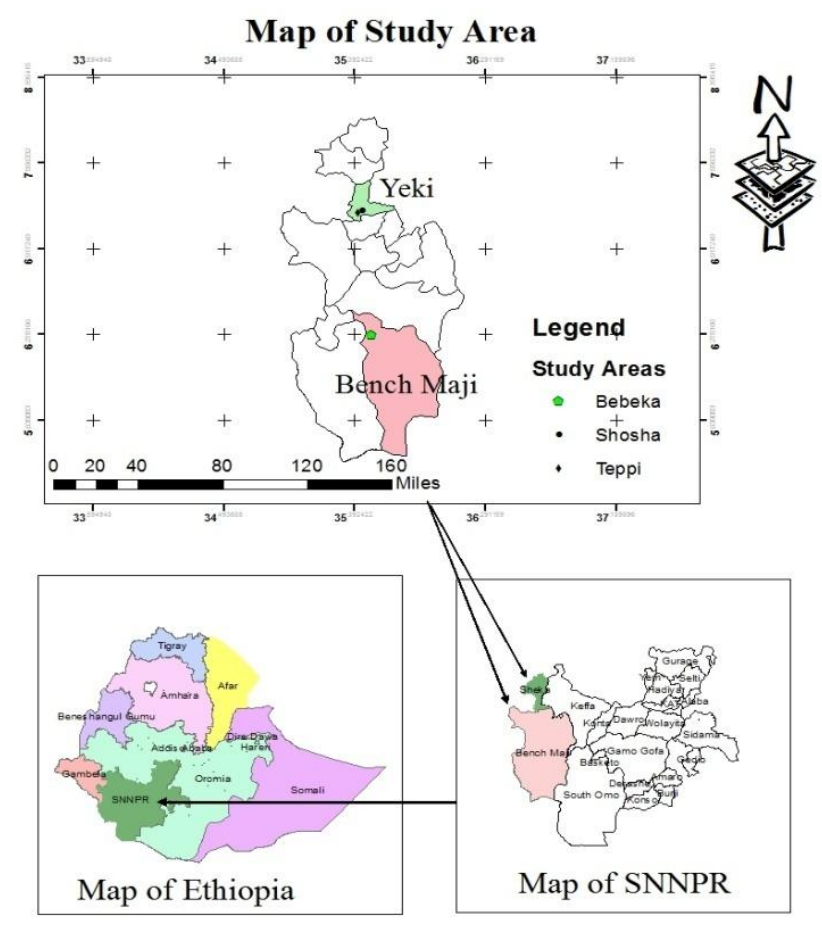

Fig1. Map of the study area

\subsection{Experimental Design and Data Collection}

The activity was conducted in south west Ethiopia SNNP regions in two zones Sheka and Bench Maji in a total of three locations. The description of the testing location is summarized in table 1. One variety of vanilla introduced from Indonesia Bali Island was evaluated for its adaptability, yield and quality using single observation plot. A spacing of $2 \mathrm{~m}$ was maintained between rows and plants. Three months old Seedlings were transplanted to the field and a total of 100 plants were planted in each area. Data were collected on: vine girth and number of inflorescence per vine, number of flowers per inflorescence, number of pods per inflorescence, number of pods per plant, length of pod, pod yield and finally quality (vanillin content).

\section{RESULT AND DISCUSSIONS}

\subsection{Propagation of Vanilla through Nodal Cutting and Tissue Culture}

The study conducted to determine vanilla node number cuttings on nursery performance and mass propagation and protocol development results four node vanilla ( $V$. fragrans) cutting were found best for raising seedling from nodal cutting (Girma et al. 2012) and. Study on mass propagation of vanilla plant by tissue culture at Jimma results efficient and reproducible tissue culture based mass propagation protocol for elite vanilla clones developed. An average number of 3.12 to 4.17 shoots were obtained after 45 days of nodal culture on MS media supplemented with BA combined with KIN and NAA (Zerihun Abebe et al., 2009).

\subsection{Field Establishment and Planting}

Three months old vanilla seedling raised in Tepi National Spices Research Center was planted in three locations during 2006 planting season. Vanilla is having climbing vines. Like all climbing plants, it needs support to grow to reach its full height. The advantage of shade and support is that it is provided with shelter from excessive exposure to the sun and strong winds. So far we do use gravelia as a shade tree and use bamboo as artificial support, but it is difficult to practice and require high cost. So, we introduce to the area the recommended support and shade tree Gliricidia sepium which is a legume contribute nitrogen to the soil, easily to propagate, fast growing and have deep roots so that nutrition in the upper soil layers, where the vanilla takes root, is not depleted.

During planting seedlings are set close to a previously planted climbing tree (the so-called 'tutor'). The vine is not allowed to climb freely up the tutor tree, but is regularly guided back to the ground to 
promote the growth of new roots in the soil. This method provides an ample supply of nutrients and triggers fast vegetative growth. Approximately two to three years after the vanilla vine was first planted, its head is pruned together with other parts of the plant, which in turn triggers physiological stress and induces flowering. The plant starts producing fruit after three to four years and is usually exhausted after eleven years at Tepi condition.

Table.2. Survival rate

\begin{tabular}{|l|l|l|l|}
\hline Location & Initial number of plants & Number of plant survived and give yield & Percent survival \\
\hline Tepi & 100 & 98 & 98 \\
\hline Bebeka & 100 & 80 & 80 \\
\hline Shosha & 100 & 93 & 93 \\
\hline
\end{tabular}

\subsection{Result of Selection and Preparation of Support Tree}

Vanilla is originally a forest plant and it therefore requires a similar forest environment. It must have a support tree to support its stem and to provide about $50 \%$ shade for good growth. However, the need to continually prune these trees to provide the optimum shade makes it necessary to select the best support tree, which are quick growing, easily propagated, provide light, chequered shade and have sufficient low branches over which the vines can be trained to hang down, with a type of growth providing easy access to the vanilla, and be easily pruned when necessary.

Table3. Available support and shade tree in Ethiopia

\begin{tabular}{|l|l|l|l|}
\hline Scientific name & Common name/Amharic & Method of propagation & Suitability \\
\hline Gliricidia sepium & Yeelka zaf & By seed and cutting & Best \\
\hline Erythrina orientalis & korch & By seed and cutting & Best \\
\hline Jatropha carcas & Kobo & By seed and cutting & Medium \\
\hline Casuarna equisetifolia & shewshawe & By Seed & Medium \\
\hline Gravilieae & Gravelia & & Medium \\
\hline
\end{tabular}

\subsection{Flowering and Pollination}

Although vanilla flowers possess stigma and stamen (the flower's male and female reproductive organs), self-pollination is impossible because the two organs are separated by a thin membrane. In nature's own process, the blossoms are pollinated by certain melipona bees or hummingbirds which are to be found only in the native regions of the cultivated vanilla species (Mexico). Moreover, this process does not result in the systematic pollination of all blossoms of a flowering vanilla vine. To overcome this biological (and commercial) barrier, vanilla is pollinated by hand. This labor-intensive method has to be applied daily throughout the four-month blooming season, simply because the individual vanilla flower is open for less than 24 hours and is receptive to pollination only for a brief period of eight to twelve hours. In other country a good worker can pollinate up to 1500 flowers in one day, but in our experience one person can pollinate up to 100 flowers per hour. Vanilla flowers and the resulting pods grow on several panicles per plant. On each panicle only a limited number of well-developed beans are allowed to mature; this ensures good quality beans of the desired length (10$25 \mathrm{~cm}$ ). A single vanilla plant can produce up to 150 pods per harvesting period.

\subsection{Maturity and Harvesting}

The green vanilla beans eventually mature and are ready for picking when the color of their base turns from green to a yellowish hue - approximately seven to eight months after pollination. Harvesting the beans at this stage will provide the best flavor quality and vanillin content in the processed vanilla beans. If they are picked too early, the beans will have lower vanillin content and are more susceptible to mould during subsequent processing and storage. Beans picked too late develop well in flavor and vanillin but tend to burst at the base and are thus inferior in appearance, which has a detrimental effect on their sale price.

Table.4. Response of vanilla fragrance for yield and yield related parameters in three location

\begin{tabular}{|l|l|l|l|}
\hline Parameters & $\begin{array}{l}\text { Tepi } \\
\text { Range }\end{array}$ & $\begin{array}{l}\text { Shosha } \\
\text { Range }\end{array}$ & $\begin{array}{l}\text { Bebeka } \\
\text { Range }\end{array}$ \\
\hline Leaf Length $(\mathrm{cm})$ & $19.04-14.3$ & $20.8-15.9$ & $21.2-13.2$ \\
\hline Leaf Width $(\mathrm{cm})$ & $4.66-3.7$ & $5.8-4.6$ & $6.2-2.8$ \\
\hline Bean Length $(\mathrm{cm})$ & $14.85-11.88$ & $15.96-12.46$ & $17.55-12.8$ \\
\hline
\end{tabular}


Habetewold Kifelew et al.

\begin{tabular}{|l|l|l|l|}
\hline \hline Bean girth (cm) & $1.88-0.63$ & $0.98-0.66$ & $3.65-2.8$ \\
\hline Bean fresh Weight (gram) & $10.27-6.01$ & $16.4-9.7$ & $15.3-10.4$ \\
\hline Bean dry Weight (gram) & $2.57-1.29$ & 2.57 & 1.29 \\
\hline Inter nod length (cm) & $11.7-8.9$ & $14.3-11.1$ & $18.2-10$ \\
\hline Vanillin content (\%) & $1.7-2.5$ & $1.8-2.56$ & $1.6-2.49$ \\
\hline Flowering day & January to march & January to march & January to march \\
\hline $\begin{array}{l}\text { Days flowering to fruit } \\
\text { maturity }\end{array}$ & $9-8$ months & $9-8$ months & $9-8$ months \\
\hline No. flower/inflorescence & $20.6-10.8$ & $20.6-10.8$ & $20.6-10.8$ \\
\hline No. of inflorescence/vine & $18-8$ & $18-8$ & $18-8$ \\
\hline $\begin{array}{l}\text { No. bean } \\
\text { /inflorescence }\end{array}$ & $15.3-12.6$ & $11.6-3.6$ & $15.3-12.6$ \\
\hline $\begin{array}{l}\text { Yield of green bean } \\
\text { vanilla/tree(gm) }\end{array}$ & 455.04 & 455.04 & 455.04 \\
\hline $\begin{array}{l}\text { Yield of curried bean } \\
\text { vanilla/tree (gm) }\end{array}$ & 81.29 & 81.29 & 81.29 \\
\hline Flower bundle length & $6-8$ & $4.5-7.9$ & $4-7.7$ \\
\hline
\end{tabular}

Vanilla is a perennial vine and it remains in commercial production for 5 to 6 years if well-managed. A mature plant of 3 to 4 years can produce 80-100 beans per year (). A pure stand of vanilla can produce yields of up to $2,700-3,000 \mathrm{~kg}$ per hectare of green beans which translates to 500 to 600 kilograms of cured beans() where as from the adaptation trial in Ethiopia mean yield of curried been per hectare 204 kilogram were found.

Table 5. Processing of vanilla and required time

\begin{tabular}{|l|l|l|}
\hline No. & Activities/phases & Required time \\
\hline 1 & Harvest & Day 1 \\
\hline 2 & Sorting \& grading & Day 1 \\
\hline 3 & Water or sun killing & Day 1 \\
\hline 4 & In-Box starting & Day 1 to day 348 hours \\
\hline 5 & Sun curing and in-box sweating & Day 3 to day 18,15 days \\
\hline 6 & In-shed curing & Day 18 to day 90,60 days \\
\hline 7 & Sorting and bundling & Day 90 \\
\hline 8 & In-box conditioning & Day 90 to day 120,30 days \\
\hline
\end{tabular}

\section{REFERENCES}

[1] Girma H, Digafie T, Habtewold K, and Haimanot M, 2012. The Effect of Different Node Number Cuttings on Nursery Performance of Vanilla (Vanilla planifolia syn. Vanilla fragrans) in south western Ethiopia, International Research Journal of Agricultural Science and Soil Science (ISSN: 2251-0044) Vol. 2(9) pp.44

[2] Zerihun Abebe, Ayelign Mengesha, Alemayehu Teressa and Wondyfraw Tefera, 2009. Efficient in vitro multiplication protocol for Vanilla planifolia using nodal explants in Ethiopia. African Journal of Biotechnology Vol. 8 (24), pp. 6817-6821,

[3] Severine Bory, Pesach Lubinsky, Ange-Marie Risterucci, Jean-Louis Noyer, Michel Grisoni, Marie-France Duval and Pascale Besse, 2008. Patterns of introduction and diversification of Vanilla planifolia (Orchidaceae) in Reunion Island (Indian Ocean) Am. J. Bot. July 2008 vol. 95 no. 7 805-815

[4] Ranadive, A.S. (1994) Vanilla cultivation, curing, chemistry, technology and commercial products. In: Charalambous, G. (ed.) Spices, Herbs and Edible Fungi. Elsevier, Amsterdam, pp. 517-577.

[5] Sebsebe Demissew, Cribb, P. J. and Rasmussen, F. (2004). Field Guide to Ethiopian Orchids. Royal Botanic Gardens, Kew

[6] Agribusiness Development Center (ADC), 2000. Vanilla, Commercialization bulletin "1. published by the Agribusiness Development Centre of the USAID-funded Uganda's Investment in Developing Export Agriculture (IDEA) Project 